\title{
PHYLLOPLANE MYCOFLORA ON VIGNA SINENSIS L.
}

\author{
SHAMIM SHAMSI ${ }^{1}$ AND NAJMUN NAHER ${ }^{2}$ \\ Department of Botany, University of Dhaka, Dhaka-1000, Bangladesh \\ Key words: Phylloplane, Mycoflora, Vigna sinensis
}

Vigna sinensis L. (Cowpea) is a leguminous plant found throughout the tropics of the world. It is extensively cultivated in the southern united states of America for fodder, and seeds used as food for man. The plant is a annual herb. Its most notable nutritional compound is protein. Pods and seeds of cowpea is most often used dried, freshed or water boiled. In the present study phylloplane mycoflora was investigated on $V$. sinensis L. The plant is attacked by fungal diseases along with bacteria, viruses, nematodes and pests. Most common fungal diseases are anthracnose caused by Colletotrichum lindemuthianum (Sacc. \& Magn,) Br. \& Cav., wilting caused by Fusarrium oxysporum, Schlecht, Verticellium Nees., powdery mildew caused by Erysiphe poligoni DC, Oidium cyparissiae Syd., Shaerotheca phaseoli, Phyllactinia vignae Speg., leaf spot caused by Cercospora cruenta. Sacc., rust caused by Uromyces appendiculatum (Pers.) Blight caused by Alternaria alternata (Fr.) Keisser. Aspergillus niger Van Tiegh. and Cladosporium Link., are also reported on cowpea.

Before flowering stage of plant growth, the wide spread occurrence of rust fungus was noticed on leaflets of cawpea in the field plot of Botanical Garden, Curzon Hall Campus. Present study was undertaken (i) to investigate the phylloplane mycoflora on cowpea and (ii) to find the interaction between the fungi.

From infected samples of cawpea, associated with fungi were isolated following "Tissue planting" on PDA medium at pH 6 and temperature 18 to $24^{\circ} \mathrm{C}$;. and "Blotter" method.(1) Except Oidium sp. and $U$. appendiculatus all the above mentioned fungi were isolated in culture medium. The specimens examined and isolates were preserved in the Mycological Herbarium, Department of Botany, University of Dhaka, Bangladesh.

Microscopic details, digital and microphotograph of the specimens were taken from fresh material collected from the field plot. Identification of fungi were done following relevant literatures. ${ }^{(2-5)}$

Initially leaflets of Vigna sinensis was infected by the rust fungus Uromyces appendiculatus (Pers.). Urediospores of the rust fungus were deposited on the leaflets of $V$. sinensis, then upon germination of spores the plants were sevearly infected. From 15th

${ }^{1}$ Corresponding author. ${ }^{2}$ Department of Botany, Life and Earth Science Group, National University, Gazipur-1704, Bangladesh. 
January to 25th January 2009, the rust was the predominating fungus on cawpea. Teleospores of the fungi were formed in moist chamber in vitro (Figs. 1A and 2A, B). Up to 31st January urediospores of rust fungi gradually declined. After Ist February 2009
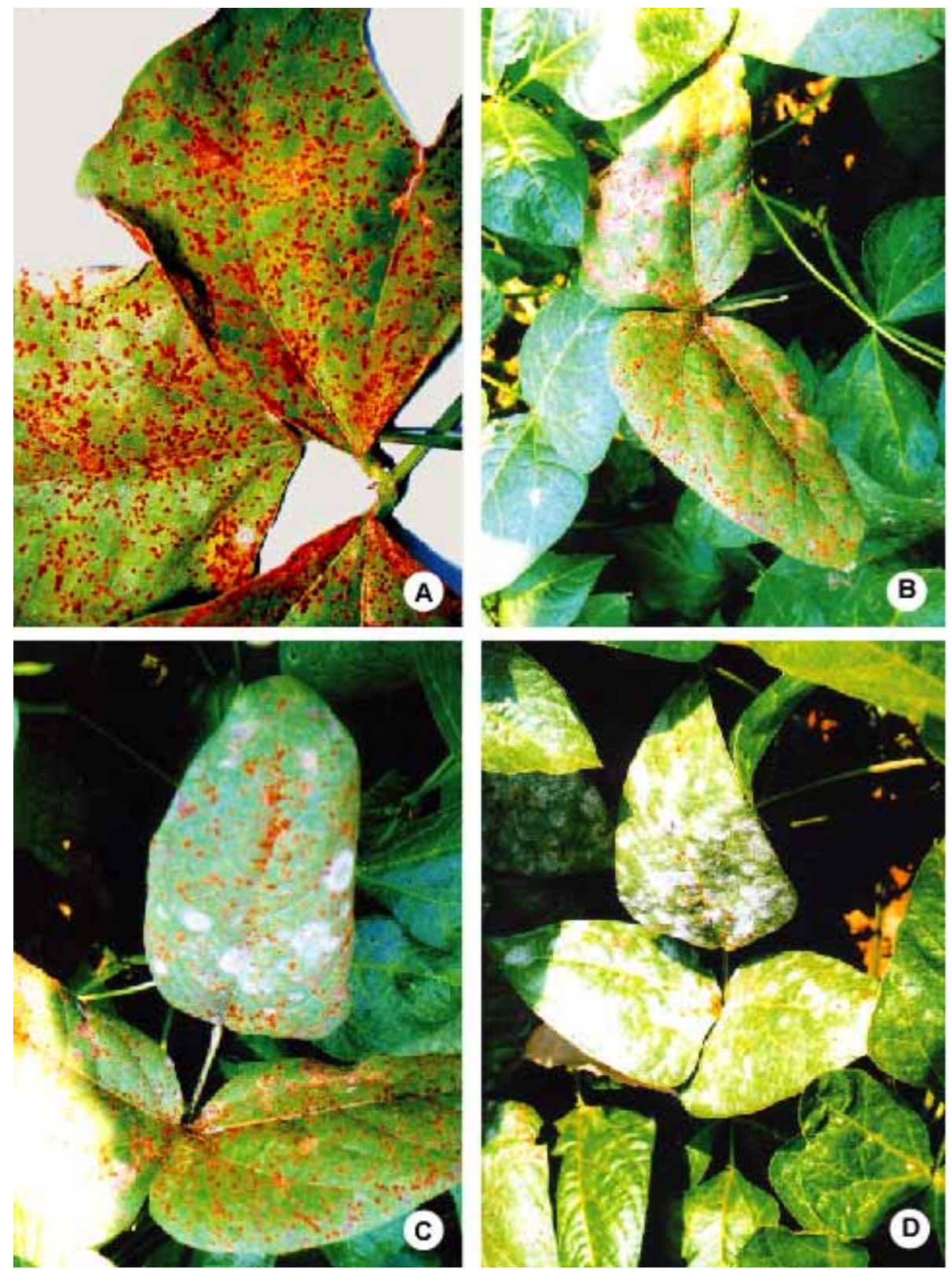

Fig. 1. Infected leaflets of Vigna sinensis. A. Rusty pustules. B. Rusty pustules with blight symptom.

C. Rusty pustules replacing by powdery mildew colonies. D. powdery mildew colonies. 
Alternaria alternata (Fr.) Keissler, Arthrenium Kunz.., Botryodiplodia theobromae, Pat, Cercosporella sp., Chladosporium sp., Chaetomium sp., Curvularia Boidijn and Sorderia sp. were found associated with the samples showing blight and rust symptoms (Fig. 1B), but Arthrenium sp. was the predominated fungus. A few spores of Fusarium sp., Cercospora sp., and Corynespora cassiicola (Berk. \& Curt.) were also found associated with the infected leaflets. From 27th January the white colony of powdery mildew was also recorded on the older leaflets of the vegetation. After 31st January at the flowering stage of plant growth, the older leaflets dried up and younger leaves of $V$. sinensis were found infected with fresh colony of powdery mildew (Oidium sp.). Rust spores are rapidly replaced by oidiospores of Oidium sp. (Fig. 1C, D). The most frequently associated fungi on phyllolpane of $V$. sinensis have been presented in Fig. 2A-H.
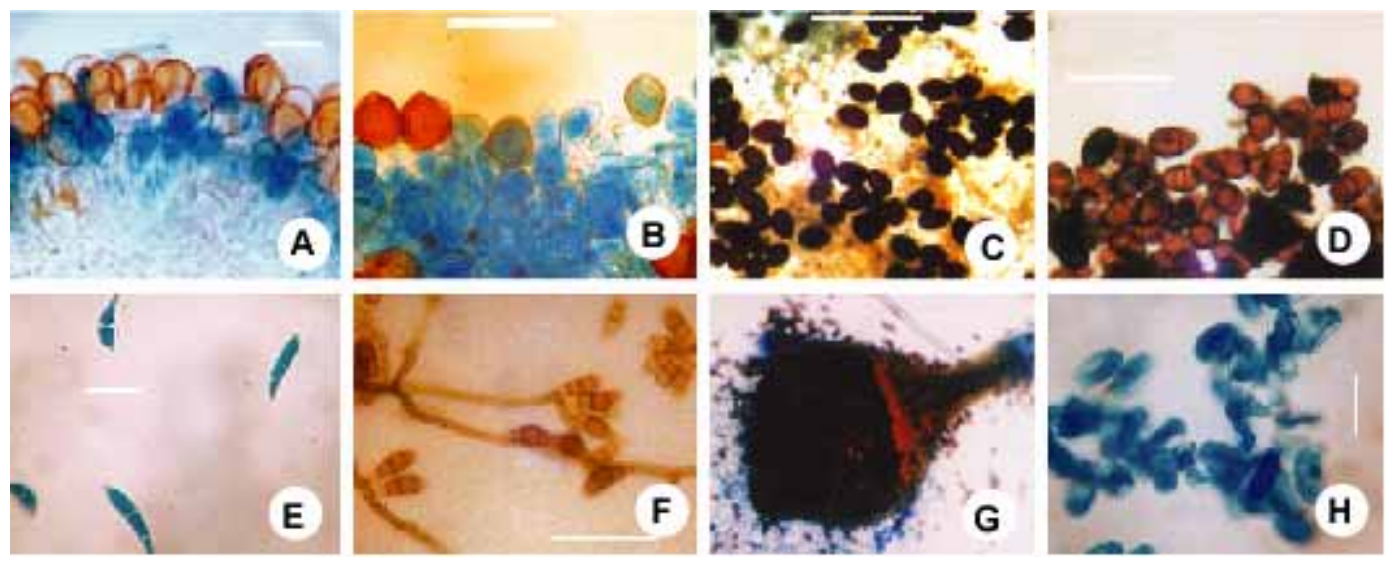

Fig. 2. A. Uredospore with uredeosorus (Uromyces appendiculatas). B. Teleospore with teleosorus (Uromyces appendiculatas). C. Arthrinum sp. D. Botryodiplodia sp. E. Cercosporella sp. F. Curvularia sp. G. Sordaria sp. H. Oidium sp. Bar $=100 \mu \mathrm{m}(\mathrm{A}, \mathrm{B}, \mathrm{H})$ and $50 \mu \mathrm{m}(\mathrm{C}, \mathrm{D}, \mathrm{E}, \mathrm{F}, \mathrm{G})$.

In total 13 species of fungi were recorded on cowpea within four weeks, which drastically killed the cowpea foliage vegetation. Among the associated fungi $U$. appendiculatus is Basidiomycetous fungus. Chaetomium sp. and Sordaria sp. are Acomycetous fungi. Uromyces appendiculatus and Oidium sp. are biotrophs. The other fungal partners of the mycoflora viz. A. alternata, Arthinium sp., B. theobromae, Cercospoa sp., Cercosporella sp., Chladosporium sp., C. cassiicola, Fusarium sp. and Oidium sp. are members of Form-Class Deoteromycetes and these are necrotrophs. Aternaria alternata, and Chladosporium sp. are commonly found on the aerial surfaces of many higher plants throughout the temperate regions. These two species are known to be capable of sporulating vigourously on newly dead plant remains.

From Bangladesh this is the first report of Arthrenium sp., Cercosporella sp., $B$. theobromae and Sorderia sp. on V. sinensis. 
Mishra and Tewari investigated the interactions between phylloplane saprophytic fungi and Puccinia tritici and showed that rust fungi may suppressed by saprophytes.(6) The nature of the surface of the leaf affects trapping efficiency. Rapilly and Fourcault have reported that Puccinia atriifomis uredispores are deposited more rapidly on smooth leaves than on hairy ones.(7) The orientation of the leaf is also important. Russell showed that the stiff, vertical leaves of the wheat cultiver W 1343 only retained one third the number of spores deposited on the lax than horizontal leaves Capelle-Desperz or little Joss. ${ }^{(8)}$

The leaflets of cowpea is fleshy, tender, smooth and shinning, Orientation of the leaflets are slightly oblique. From the above discussion it seems that orientation and nature of leaflets were facilitated attack of rust and other fungi on cowpea. At the same time low temperature between 14 to $20^{\circ} \mathrm{C}$, dew drops and $75-80 \%$ humidity was also fevourable for growth and reproduction of the fungi. More research should be done on phylloplane mycoflora to know about the nature of the fungi which will be helpful for designing management of leaf surface fungi.

\section{Acknowledgements}

The authors express their sincere thanks and gratitude to Professor Md. Abul Hassan, Chairman, Department of Botany, University of Dhaka for providing all laboratory facilities to carry out the present research work.

\section{References}

1. CAB (Commonwealth Agricultural Bureau) 1968. Plant Pathologist's Pocket Book. The Commonwealth Mycological Institute, Kew, Surrey, England, pp. 1-267.

2. Arthur JC 1982. Progress of rust studies. Phytopathology 18: 659-675.

3. Braun U. 1987. A monograph of the Erysiphales (Powdery mildews). Beih. Nova Hedwigia 89: $1-700$.

4. Ellis MB 1971. Dematiaceous hyphomycetes. The Commonwealth Mycological Institute, England, pp. 608.

5. Ellis MB 1976. More Dematiaceous hyphomycetes. The Commonwealth Mycological Institute, England, pp. 507

6. Mishra RR and RF Tewari 1976. Studies on biological control of Puccinia graminis tritici. Microbiology of Aerial plant surface (C.B. Dickinson and T.F. Preece, eds) pp. 559-567. Academic Press, London.

7. Rapilly F and B Fourcault 1976. Premieres etudes sur la retention de spores fongiques par des epidermes foliares Ann. Phytopathhol. 8: 3140.

8. Russel GH 1976. Germination of Puccinia striiformis urediospores on leaves of adult winter wheat plants. Ann. Appl. Bios. 82: 71-78.

(Manuscript received on12 September, 2009; revised on 3 April, 2010) 